ISSN 1112-9867

http://www.jfas.info

\title{
REMOVAL OF ZINC AND CADMIUM IONS FROM CONTAMINATED SOILS WITH RHAMNOLIPID BIOSURFACTANT PRODUCED BY PSEUDOMONAS AERUGINOSA S7PS5
}

\author{
M. E-A. Bendaha ${ }^{1 *}$, B. Meddah ${ }^{1}$, H. A. Belaouni ${ }^{2}$, M. Mokhtar ${ }^{3}$ and A. Tirtouil ${ }^{1}$ \\ ${ }^{1}$ Laboratoire de Bioconversion, Génie Microbiologique et Sécurité Sanitaire (LBGMSS), \\ University of MASCARA, Algeria \\ ${ }^{2}$ Laboratoire de Biologie des Systèmes Microbiens (LBSM), ENS KOUBA, Algeria \\ ${ }^{3}$ Laboratory of Beneficial Microorganisms, Functional Food and Health (LMBAFS), \\ University of MOSTAGANEM, Algeria
}

Received: 04 June 2016 / Accepted: 20 August 2016 / Published online: 01 September 2016

\begin{abstract}
A soil treatment process using froth flotation technique involving anionic biosurfactant (rhamnolipids) using Sodium sulfide was studied. The supernatant produced by the strain Pseudomonas aeruginosa S7PS5 was tested for biosurfactants production, HPLC analysis showed the presence of L-rhamnosyl- $\beta$ - hydroxydecanoyl- $\beta$-hydroxydecanoate (RL1) and L-rhamnosyl L-rhamnosyl- $\beta$-hydroxydecanoyl- $\beta$ - hydroxydecanoate (RL2). The influence of the collector (rhamnolipid), pulp $\mathrm{pH}$, a chemical activation step (sulfidization) and process time on metal removal efficiency has been investigated to recover $\mathrm{Zn}$ and $\mathrm{Cd}$ ions from a contaminated soil. An effective CMC of $35 \mathrm{mg} / \mathrm{L}$ was obtained. A perfect $\mathrm{Zn}$ and $\mathrm{Cd}$ removal efficiency was made at $\mathrm{pH}=12$ and $4 \mathrm{mg} / \mathrm{g}$ of $\mathrm{Na}_{2} \mathrm{~S}$ during the first $5 \mathrm{~min}$ of soil washing process, then a longer flotation time ( $>5 \mathrm{~min}$ ) caused mechanical entrainment of $\mathrm{Zn}$ and $\mathrm{Cd}$.
\end{abstract}

Keywords: Biosurfactants, flotation, Pseudomonas aeruginosa, rhamnolipids, soil washing.

Author Correspondence, e-mail: biodaha@live.com

doi: http://dx.doi.org/10.4314/jfas.v8i3.27 


\section{INTRODUCTION}

The presence of low concentrations of heavy metals in the soils are known to have potential impact on environmental quality and human health via ground water, surface water, plants and agricultural products [1].

Soil composition, clay mineralogy, permeability, $\mathrm{pH}$, cation exchange capacity, particle size and other factors such as the presence of competing ligands, the ionic strength of the soil and the simultaneous presence of competing metals and contaminants significantly affect sorption-desorption processes and leaching potential through a soil profile [2, 3].

Cadmium $(\mathrm{Cd})$ and zinc $(\mathrm{Zn})$ have a great interest because of their high toxicity and mobility in soil and as metals in the contaminated sites are not degraded, they must be either immobilized or removed [1].

Biosurfactants over synthetic surfactants include higher selectivity for metals and organic compounds [4], lower toxicity, higher biodegradability, higher foaming [5], better environmental compability, less expensive, more tolerant to $\mathrm{pH}$, salt, and temperature variation [6].

Rhamnolipids are mostly produced by Pseudomonas aeruginosa, which are composed of one or two rhamnose molecules as a hydrophilic portion, and up to three molecules of hydroxy fatty acids (C8-C14) as a hydrophobic portion [7]. These surfactants have been studied in various environmental applications and are applied to the removal of $\mathrm{Zn}$ and $\mathrm{Cd}$ [1].

\section{MATERIALS AND METHODS}

\subsection{Sampling site}

The soil used for the washing tests was collected from Sidi Bel Abbess (Algeria) at the agricultural engines factory (SONACOM) (depth of $15-100 \mathrm{~cm})$. The soil samples were dried at $105{ }^{\circ} \mathrm{C}$ and sieved $(<2 \mathrm{~mm})$ according to AFNOR $\mathrm{X}$ 31-101 standard [8], then homogenized and kept away from light.

\subsection{Rhamnolipids production and purification}

The used rhamnolipids were produced by Pseudomonas aeruginosa S7PS5 (Figure 1) (GenBank accession no. KR349493) isolated by Bendaha et al. [9] after a culture of $22 \mathrm{~h}$ at 
room temperature in the following media: $100 \mathrm{ml}$ of nutrient broth, $1 \%$ of olive oil with $1 \%$ of inoculum with shaking at $75 \mathrm{rpm} / \mathrm{min}$ [9]. Biosurfactants are recuperated in the supernatant after centrifugation at $9000 \mathrm{~g}$ for $15 \mathrm{~min}$ [10].

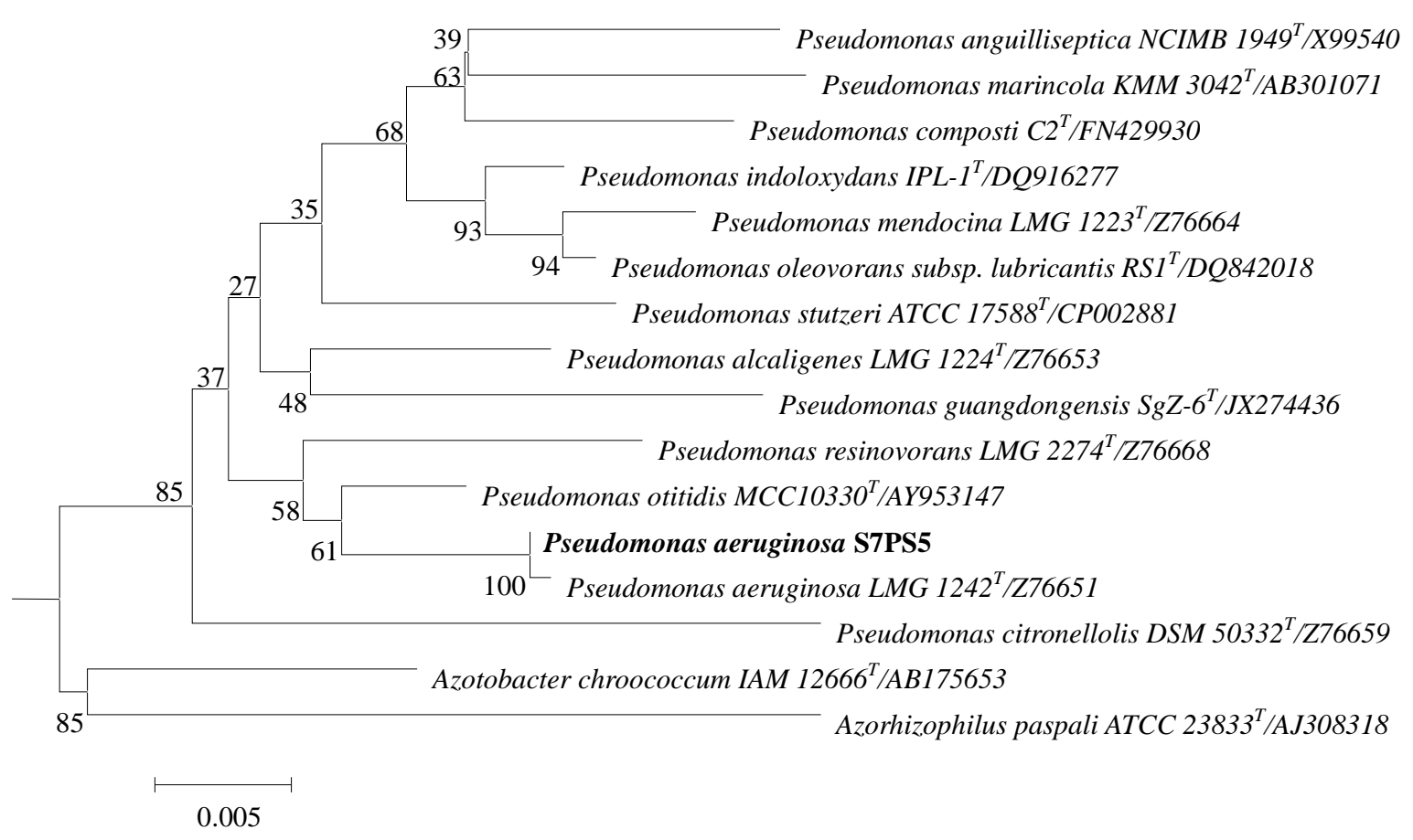

Fig. 1. Phylogenetic tree based on sequence analysis of 16S rDNA and showing the relationships between Pseudomonas aeruginosa S7PS5 and the other similar species.

Note: The numbers at the nodes indicate "bootstrap" levels (As a percentage of 1000 re-sampling). The bar indicates 0.005 substitutions per nucleotide position [9]

\subsection{Biosurfactants producing tests}

The drop collapsing was conducted using the test of collapse described by Jain et al. [11], supernatant of the culture that led to the collapse of the drop is shown as a positive result, and the drops remaining with the beads are marked as negative results [9].

$15 \mu \mathrm{L}$ of crude oil are placed on the surface of $40 \mathrm{ml}$ of sterile distilled water for the oil displacement test, then; $10 \mu \mathrm{L}$ of supernatant was slightly put on the oil film surface. After $30 \mathrm{~s}$, diameter of the clear halo is measured under visible light [12].

For the emulsification activity was done according to Paraszkiewicz et al. [13]. The emulsification index $\left(E_{24}\right)$ was estimated after $24 \mathrm{~h}$, as follows: 


$$
E_{24}(\%)=\frac{H_{E L}}{H_{S}} \times 100
$$

$H_{E L}$ : Height of emulsion layer, $H_{S}$ : Height of total liquid column.

The surface tension measurement was carried out according to the Du Nouy ring method described by Zajic et al. [14] and the surface activity is expressed as a reduction percentage of the surface tension reduction by the following equation:

$$
\% \text { surface tension reduction }=\frac{\left({ }_{n}-c_{c}\right)}{r} \times 100
$$

$m$ is the surface tension of the medium as prepared, ${ }_{c}$ is the surface tension of the supernatant.

\subsection{Rhamnolipids purification}

Supernatant was collected after centrifugation at $9000 \mathrm{~g}$ for $15 \mathrm{~min}$, rhamnolipids were then precipitated by acidification at $\mathrm{pH}=2$ using $1 \mathrm{~N} \mathrm{HCl}$ [10]. A second centrifugation was done at $9000 \mathrm{~g}$ for $20 \mathrm{~min}$ and the precipitate was extracted with ethyl acetate at room temperature [10]. The organic phase was transferred to a round bottom flask connected to a rotary evaporator (RE300 Stuart), allowing to remove solvent from viscous honey-colored rhamnolipid product [15]. The crude biosurfactant was purified and kept at $4{ }^{\circ} \mathrm{C}$ for $24 \mathrm{~h}$.

\subsection{Measurement of critical micelle concentration (CMC)}

Biosurfactants solutions were prepared in ultra-pure water from a solution of rhamnolipids of $1 \mathrm{~g} / \mathrm{L}$ with $\mathrm{pH}$ adjusted to 7 prior to use. The CMC determination was done by plotting the surface tension versus concentration of biosurfactant in the solution, with a curve having a downward slope to the CMC then becomes constant [16].

\subsection{HPLC analysis}

HPLC analyses of the rhamnolipids compounds were performed on a Shimadzu-system (Prominence i. LC-2030C 3D) equipped with Ascentis Express C18 column (15 cm X $4.6 \mathrm{~mm}$ ) id packed with $2.7 \mu \mathrm{m}$ partially porous particles (Supelco, Bellefonte, PA, USA). The binary mobile phase consisted of water/acetic acid (solvent A) and methanol/acetic acid (solvent B), in a linear gradient mode: $0 \mathrm{~min}, 5 \% \mathrm{~B} ; 10 \mathrm{~min}, 40 \% \mathrm{~B} ; 30 \mathrm{~min}, 70 \% \mathrm{~B} ; 60 \mathrm{~min}, 100 \% \mathrm{~B}$; $65 \mathrm{~min}, 100 \% \mathrm{~B} ; 67 \mathrm{~min}, 2 \% \mathrm{~B}$. The mobile phase flow rate was $0.7 \mathrm{ml} / \mathrm{min}$.

Pure rhamnolipids Rha $\mathrm{C} 10-\mathrm{C} 10$ and Rha-Rha $\mathrm{C} 10-\mathrm{C} 10$ were used with the testing sample. 


\subsection{Soil preparation}

The soil washing process used in this work was designed as described by Dermont et al. [17] in order to increase the degree of liberation of metal mineral phases (Figure 2). To obtain a soil with a particle-size range of 0-250 $\mathrm{m}$, a procedure combining successive sieving and crushing/grinding steps was done [18].

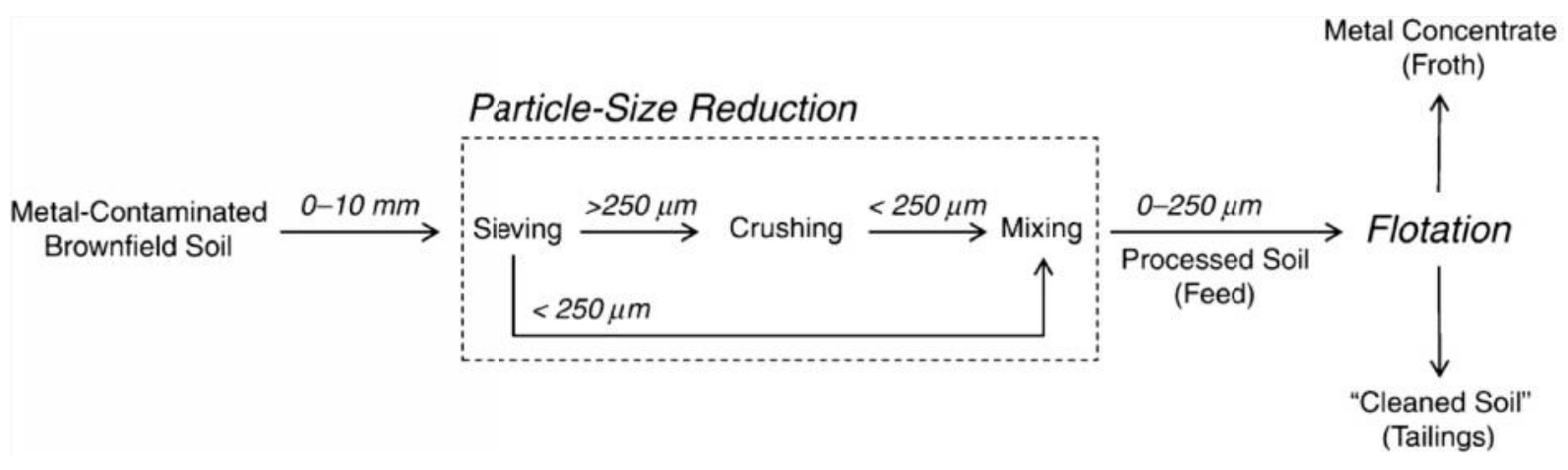

Fig.2. The schematic soil washing process [17]

\subsection{Rhamnolipids sorption}

Rhamnolipids are anionic biosurfactants that have less sorbance in soil [19].

For soil washing process, an effective CMC must be used, because in case a surfactant is sorbed in the soil, its effectiveness can be reduced.

Sorption experiment was carried out in a $250 \mathrm{ml}$ Erlenmeyer flask with $10 \%$ of soil in distilled water for $24 \mathrm{~h}$. Selected biosurfactant concentration was the same as the CMC.

The surfactant fraction attached to soil is obtained by the following formula:

$$
\text { Adsorbed } \%=\frac{\mathrm{C}_{0}-\mathrm{Cr}_{\mathrm{r}}}{\mathrm{C}_{0}} \times 100
$$

With:

$$
\begin{aligned}
& \mathrm{C}_{0} \text { : Initiale concentration of rhamnolipids }(\mathrm{mg} / \mathrm{L}) \text {. } \\
& \mathrm{C}_{\mathrm{r}} \text { : Residual concentration of rhamnolipids }(\mathrm{mg} / \mathrm{L}) \text {. }
\end{aligned}
$$

\subsection{Metals distribution and physico-chemical characterization of the soil}

The total concentration of each element ( $\mathrm{Fe}, \mathrm{Mn}, \mathrm{Zn}, \mathrm{Cu}, \mathrm{Cd}, \mathrm{Co}, \mathrm{Cr}, \mathrm{Ni}$ and $\mathrm{Pb}$ ) was measured after a complete decomposition by mixed acid digestion using an atomic absorption spectrophotometer (AAS) Perkin-Elmer model AA300, in a certified laboratory, namely the 
"Labo Bio Qual" of Blida, Algeria, where the quality control of the analytical method is ensured.

The physicochemical characterization of soil was conducted using AFNOR standard techniques [8]. These analyzes were conducted at the National Institute of Agricultural Research of Algeria (INRAA), Lamtar's Station, Sidi Bel Abbess, Algeria.

\subsection{Flotation method}

The flotation cell used in this study was developped in the Laboratoire de Bioconversion, Génie Microbiologique et Sécurité Sanitaire (LBGMSS), University of Mascara, Algeria.

The pulp pH influences the mobilization of heavy metals in surfactants presence [17], the different $\mathrm{pH}$ values used in this study are 8, 9, 10, 11 and 12 .

The experiences were realized using a laboratory flotation cell (Figure 3) with a mechanical agitator motor (Ultra-Turrax T25). Separation principle is based on the affinity of hydrophobic surfaces of particles for injected air bubbles in the soil suspension. The collector is a surfactant agent that attaches on the mineral surface (via physical adsorption or chemisorption) in order to produce a hydrophobic surface or to enhance the hydrophobic character of the mineral phase to be floated [17]. To have $10 \%$ of solids in the pulp [17], $50 \mathrm{~g}$ of soil $(0-250 \mathrm{~m})$ were mixed with the appropriate amount of distilled water in the flotation cell. The frothing agent (rhamnolipid) was added in the last minute of the conditioning step. The pulp was then conditioned for $10 \mathrm{~min}$ with the collector agent in the flotation cell with an agitation speed of $8000 \mathrm{rpm}$. After the conditioning step, the air valve was opened and flotation test was conducted for the given duration. The froth layer was continuously removed during the flotation process using a vacuum pump and collected in glass containers. After completion of the flotation stage, the various produced fractions were filtered and the concentration factor $(\mathrm{CF})$ of $\mathrm{Zn}$ and $\mathrm{Cd}$ were calculated using the equation given by Dermont et al. [17]:

$$
\text { Element CF }=\frac{[\text { Element }]_{\text {Froth }}}{[\text { Element }]_{\text {Feed }}}
$$

With:

$[\text { Element }]_{\text {Froth }}$ : Concentration of element in froth.

$[\text { Element }]_{\text {Feed }}$ : Concentration of element in feed. 


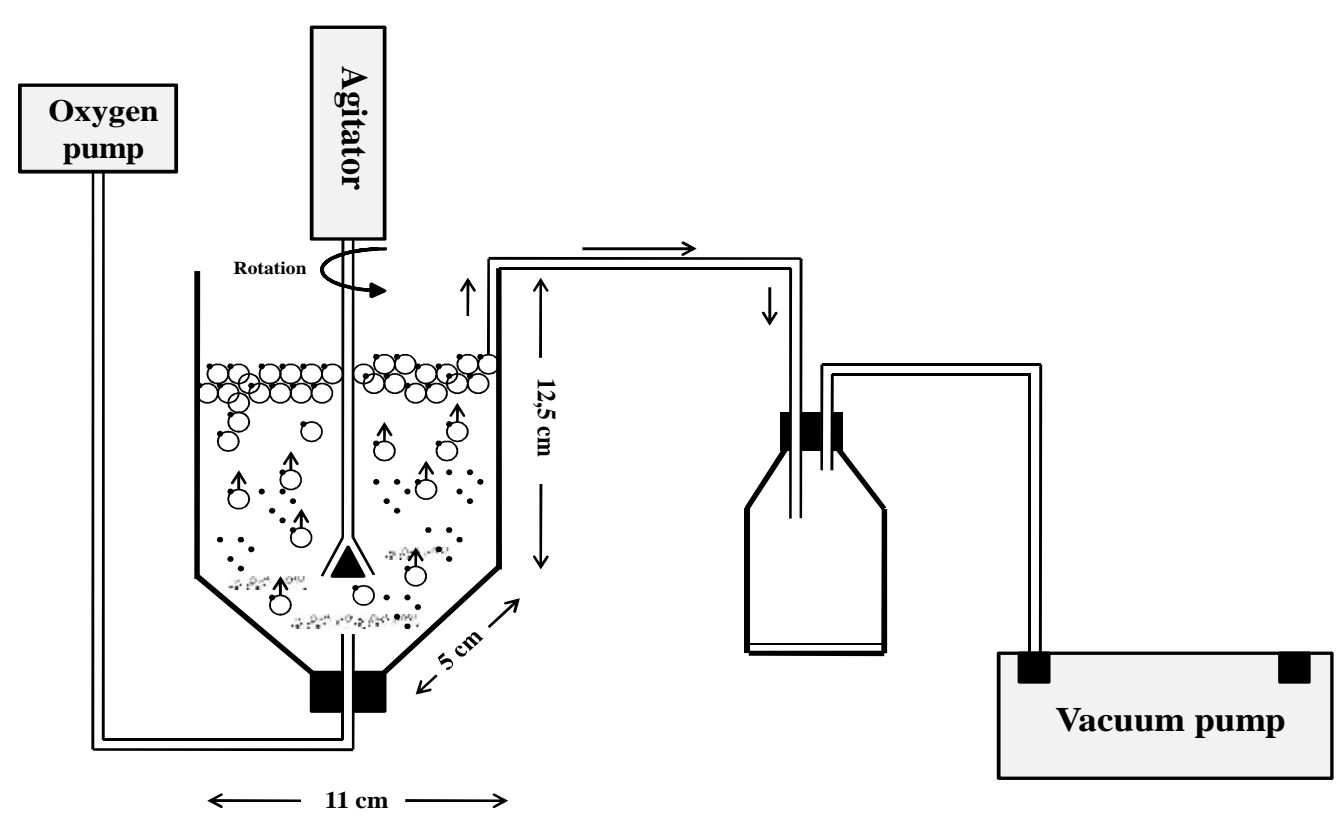

Fig.3. Process and instrumentation diagram of the flotation unit

\subsection{Influence of the chemical activation of the pulp}

The effect of chemical activation of the pulp was tested by sulfudization with sodium sulfide $\left(\mathrm{Na}_{2} \mathrm{~S}\right)$ which is generally used as a sulfurizing agent $[20,21]$. The sulfudization step was performed on $10 \%$ of soil contained in the cell for 20 minutes at room temperature [17]. Three concentrations of $\mathrm{Na}_{2} \mathrm{~S}$ were tested: 2,3 and $4 \mathrm{mg} / \mathrm{g}$. The activation by $\mathrm{HS}^{-}$ions modifies the particle surfaces to make them more disposed to the biosurfactant action.

\subsection{Influence of flotation time}

Flotation time was assessed by measuring the concentration factor (CF) and the surface activity of rhamnolipids in the pulp (10\% of soil) of $\mathrm{Zn}$ and $\mathrm{Cd}$ at four different times: $2.5,5$, 7.5, and $10 \mathrm{~min}$.

\section{RESULTS AND DISCUSSION}

\subsection{Biosurfactants producing tests}

The drop collapsing test show biosurfactants presence in the tested supernatant, interfacial tension between water droplet and hydrophobic surface is reduced resulting in the spread of 
the water drop on hydrophobic surface [22]. Clear halo diameter, $E_{24}(\%)$ and reduction of the surface tension $(\%)$ results are presented in figure 4.

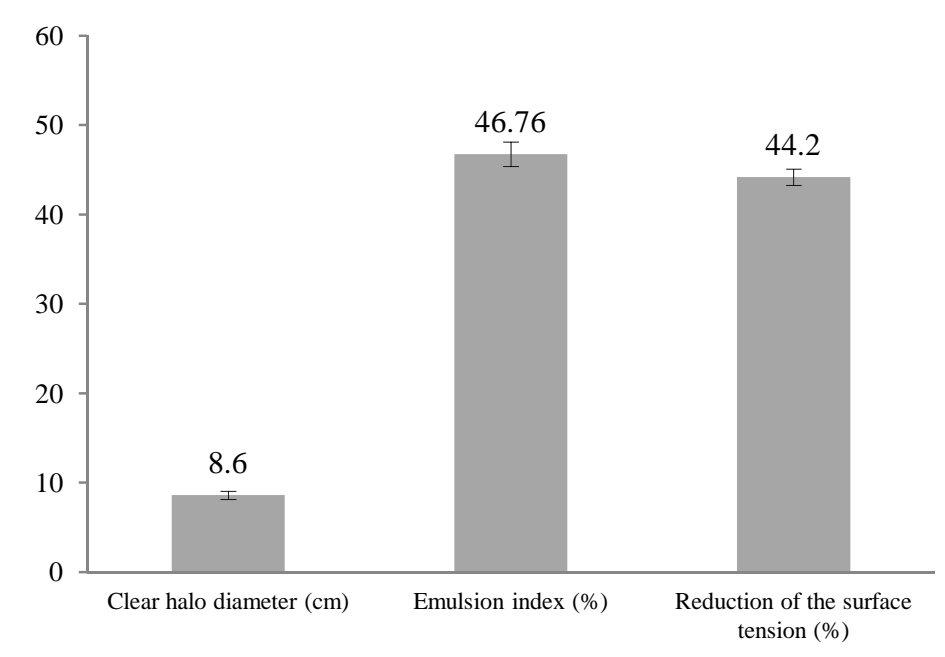

Fig.4. Biosurfactants producing tests (oil displacement, emulsion index $E_{24}$ and reduction of the surface tension) for Pseudomonas aeruginosa S7PS5

Biosurfactants have less density than water and two different polarities, so they float to the surface for the oil displacement test and will be in competition with the latter to the surface occupation [9].

Micelles are formed when hydrophobic portions unable to form hydrogen bonds in aqueous phase, unite and move towards the center leaving the hydrophilic portions outward, oil molecules were trapped in a pseudohydrophobic phase formed by micelles caused by biosurfactants which increase the solubility of hydrophobic compounds [23].

Surface tension of the supernatants was measured function to the concentration of biosurfactants excreted in order to have the surface activity of Pseudomonas aeuginosa S7PS5. Surface tension of the nutrient broth $(5.66 \mathrm{mN} / \mathrm{m})$ is rapidly decreased because of the high biosurfactants.

\subsection{Critical micelle concentration (CMC)}

Figure 5 represents the surface tension in function of biosurfactant concentration. The surface tension decreases exponentially until reaching a minimum of $40.06 \mathrm{mN} / \mathrm{m}$, for a biosurfactant concentration greater than or equal to $35 \mathrm{mg} / \mathrm{L}$. The CMC value is consistent with the reported values (27 - $54 \mathrm{mg} / \mathrm{L})$ for rhamnolipid [24]. 
For the CMC, rhamnolipids concentration from which the surface tension value begins to be stable is $35 \mathrm{mg} / \mathrm{L}$.

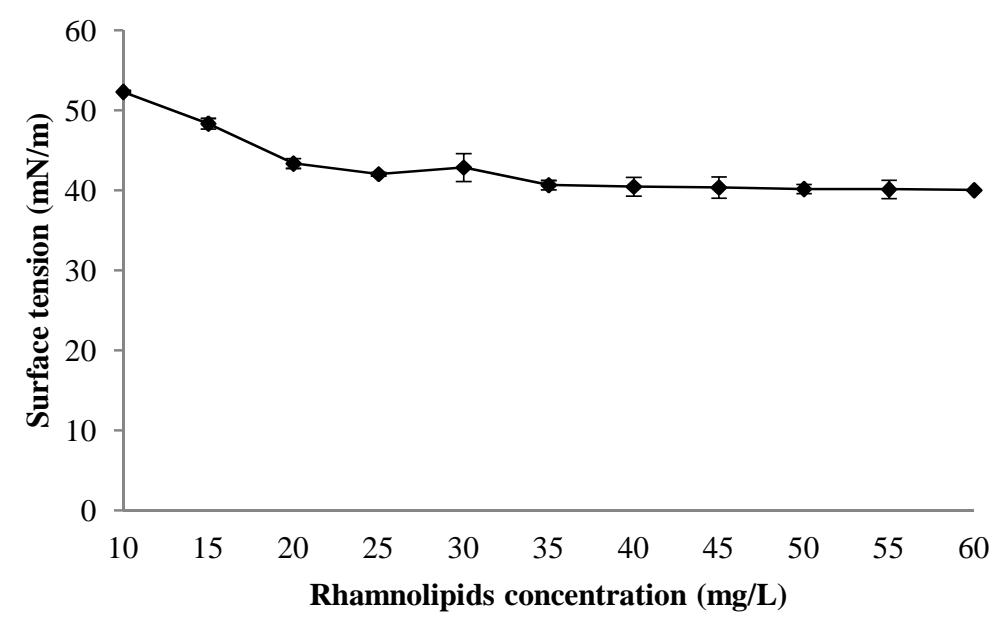

Fig.5. Surface tension vs. concentrations of rhamnolipids

\subsection{HPLC analysis}

After HPLC and comparison with the standards (Figure 6), the two major detected rhamnolipids correspond to monorhamnolipid (Rha C10-C10) and dirhamnolipid (Rha-Rha C10-C10). As reported by Wei et al. [10] and Maier and Soberon-Chavez (2000) [25], L-rhamnosyl- $\beta$-hydroxydecanoyl- $\beta$-hydroxydecanoate (RL1) and L-rhamnosyl L-rhamnosyl- $\beta$-hydroxydecanoyl- $\beta$ - hydroxydecanoate (RL2) are the two most types of rhamnolipids produced by $P$. aeruginosa species. 


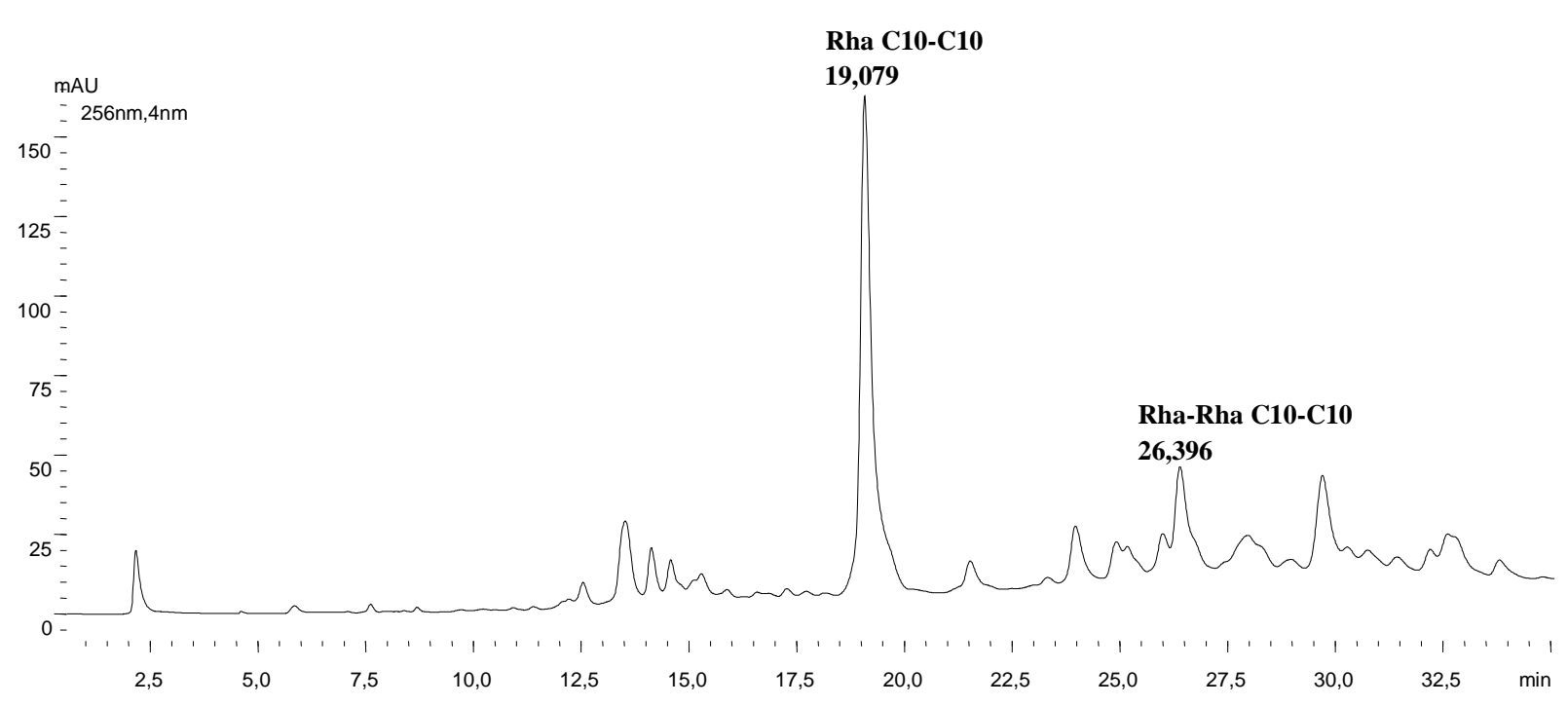

Fig.6. HPLC chromatogram of rhamnolipids from Pseudomonas aeruginosa S7PS5

\subsection{Rhamnolipids sorption}

The effective CMC is slightly greater than that obtained CMC because once the biosurfactant brought into contact with soil, the surfactant adsorbs to the matrix and thus becomes less effective, the monomers will tend to sorb to soil rather than to form micelles. The surfactant sorbed fraction after $24 \mathrm{~h}$ was $14.28 \%$. In fact, loss of biosurfactant was estimated to be $5 \mathrm{mg} / \mathrm{L}$ during the study period, the adsorption was carried out at a rhamnolipids concentration equal to $35 \mathrm{mg} / \mathrm{L}$ which corresponds to the biosurfactant $\mathrm{CMC}$ from which micelles are formed and therefore the effective CMC is $40 \mathrm{mg} / \mathrm{L}$.

\subsection{Metals distribution and physico-chemical characterization of the soil}

The characteristics of the used soil are summarized in table 1 . Concentrations of $\mathrm{Cu}, \mathrm{Ni}$ and $\mathrm{Pb}$ are undetectable by AAS because of their scarce presence, $\mathrm{Cd}$ ions presents $0.83 \mu \mathrm{g} / \mathrm{kg}$ and $\mathrm{Zn}$ with $4.02 \mathrm{mg} / \mathrm{kg}$ presents the highest metal concentration level in this soil.

The $\mathrm{pH}$ value shows that it is a neutral soil. Particle size analysis shows that the predominant fraction is slit (40\%), sand and clay are $30 \%$ for each fraction. The soil is classified as sandy clay loam as the textural triangle [26]. This allows to better assess of mechanisms involved in geochemical distribution of heavy metals such as adsorption on the surface of clay minerals, precipitation with carbonate or complexations with organic matter.

The dosage of the exchangeable cations led to highlight the predominance of calcium 
(86.85\%), indicating that the soil tends to be neutral or alkaline, which is verified by measuring the $\mathrm{pH}(7.16)$.

Clays are silicates which have a laminated structure (phyllosilicates), or fibrous (such as sepiolite or palygorskite). There are three main families of clay which are classified by the number of tetrahedral and octahedral layers that make up their sheets. The interstices between the layers may contain water molecules or ions. Clay minerals have large surface areas and large cation exchange capacity. The clays can therefore retain a significant amount of heavy metals by adsorption. Carbonate dissolution plays an important role in controlling the soil $\mathrm{pH}$. A high carbonate content raises the soil $\mathrm{pH}$. Carbonates may incorporate metal cations in their crystal lattice [27].

Table 1. General characteristics of the studied soil

\begin{tabular}{ll}
\hline Parameters & Range \\
\hline Major mineral elements $(\mathrm{mg} / \mathrm{kg})$ & \\
$\mathrm{Fe}$ & 0.65 \\
$\mathrm{Mn}$ & 1.07 \\
$\mathrm{Zn}$ & 4.02 \\
$\mathrm{Cu}$ & $<0.05$ \\
Minor mineral elements $(\mu \mathrm{g} / \mathrm{kg})$ & \\
$\mathrm{Cd}$ & 0.83 \\
$\mathrm{Co}$ & 0.71 \\
$\mathrm{Cr}$ & 0.7 \\
$\mathrm{Ni}$ & $<0.01$ \\
$\mathrm{~Pb}$ & $<0.01$ \\
Other parameters $(\%)$ & \\
$\mathrm{Soil} \mathrm{pH}$ & 7.16 \\
$\mathrm{Total}$ carbon & 2.46 \\
$\mathrm{Total}$ limestone & 22.4 \\
$\mathrm{Active} \mathrm{limestone}$ & 17.5 \\
Silt $(\%)$ & 40 \\
Clay & 30 \\
Sand & 30 \\
Exchangeable cations $($ Meq/100 g) & \\
$\mathrm{Ca}^{+2}$ & 31.72 \\
$\mathrm{Mg}^{+2}$ & 3.48 \\
$\mathrm{Na}^{+2}$ & 1.1 \\
$\mathrm{~K}^{+2}$ & 0.22 \\
\hline
\end{tabular}


The surface hydroxyl groups can be formed by hydration, this allows the adsorption of metal cations [28]. Being good adsorbents, oxides and hydroxides metal in soils also play an important role in the retention of metal ions. The amount of adsorbed ions strongly depends on the $\mathrm{pH}$ of the medium.

\subsection{Influence of the pulp $\mathrm{pH}$}

Washing soil by flotation was studied for the removal of $\mathrm{Zn}$ and $\mathrm{Cd}$ from polluted soil after grinding size fractions greater than $250 \mathrm{~m}$. This mechanical preparation allow the treatment of all contaminated fractions of any size, by obtaining an appropriate particle size for the flotation process and increase liberation degree of mineral float's phases [29].

The collector is a surfactant (rhamnolipid) which attached the surfaces of minerals (by physical adsorption or chemo-sorption) and produce a hydrophobic surface or enhance the hydrophobicity of the mineral phase to allow its flotation. The choice of using an anionic biosurfactant (rhamnolipids) is based on the results achieved by Aşçı et al. [1] and Dermont et al. [17] who shown that the use of an anionic surfactant gives better rate of metal removal. The anionic biosurfactant such as rhamnolipid carries a negative charge, so when the molecule encounters a cationic metal such as $\mathrm{Zn}$ or $\mathrm{Cd}$ that carries a positive charge, an ionic bond is formed. This bond is stronger than the metal's bond with the soil [30].

Flotation tests were carried out at alkaline $\mathrm{pH}$ as the collectors improved better stability at high $\mathrm{pH}[31]$.

Figure 7 shows $\mathrm{Zn}$ remediation by flotation using rhamnolipids produced by Pseudomonas aeruginosa S7PS5, characterized by proportional change of $\mathrm{CF}$ of $\mathrm{Zn}$ depending on its concentration in the foam which was $8.06(\mathrm{CF})$ at $\mathrm{pH}=8$ and which increased by $15.26 \%$ $(\mathrm{CF}=9.29)$ at $\mathrm{pH}=12$. A proportional change of $\mathrm{CF}$ of $\mathrm{Cd}$ depending on its concentration in the foam which was $7.56(\mathrm{CF})$ at $\mathrm{pH}=8$ and which increased by $180.42 \%(\mathrm{CF}=21.2)$ at $\mathrm{pH}$ $=12$ (Figure 8$)$. 


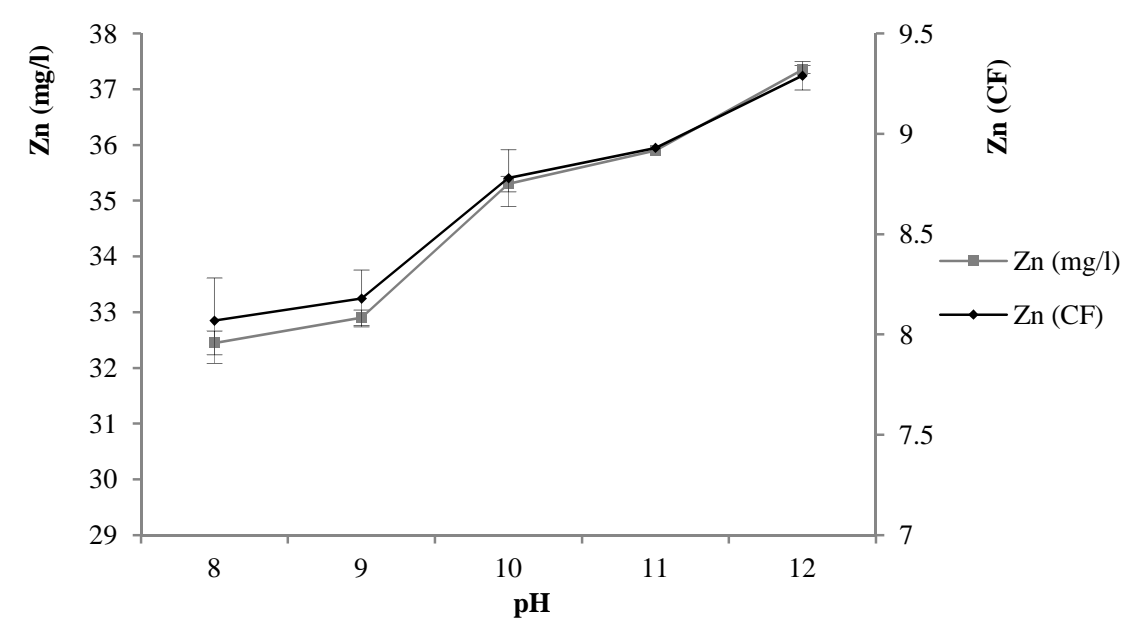

Fig.7. Influence of the pulp $\mathrm{pH}$ on $\mathrm{Zn}$ flotation using rhamnolipids

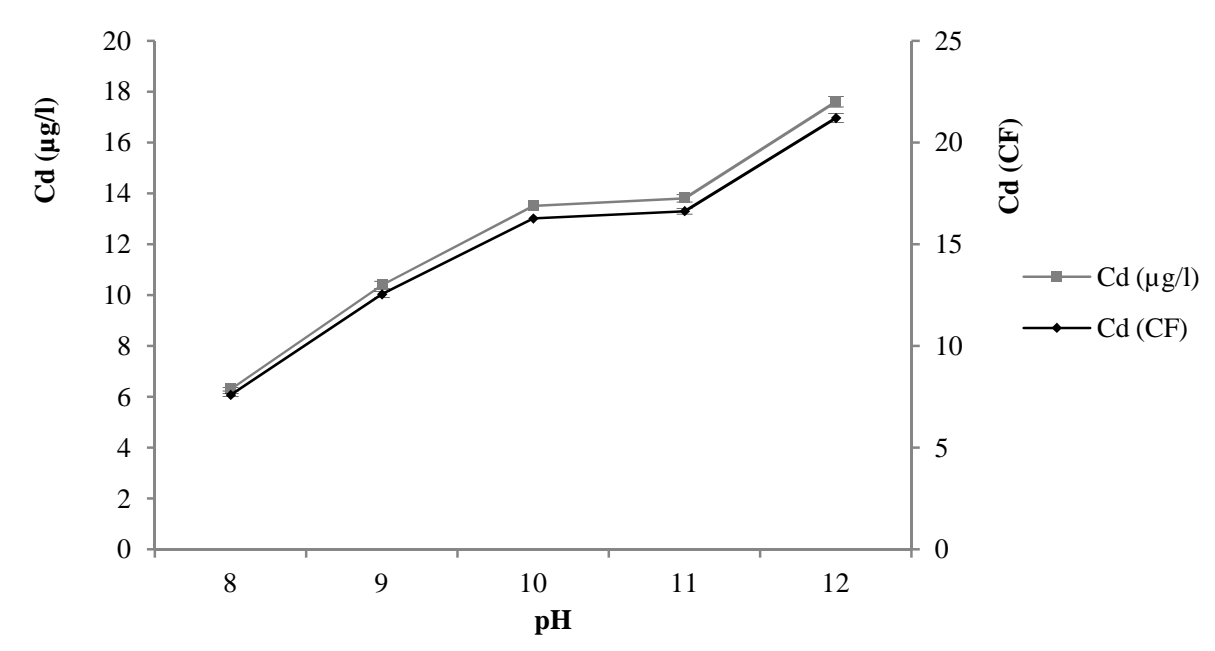

Fig.8. Influence of the pulp pH on Cd flotation using rhamnolipids

The effect of $\mathrm{pH}$ (8 to 12) of the pulp was evaluated using $0.40 \mathrm{~g} / \mathrm{L}$ of rhamnolipids, showing its influence on the flotation process. Thus, an important mobilization rate of $\mathrm{Zn}$ and $\mathrm{Cd}$ was observed which increases with increasing $\mathrm{pH}$ from 8 to 12 . The results of mobilization rate according to the increase of $\mathrm{pH}$ (8 to 12) obtained in this study join those obtained by Dermont et al. [17] with a higher $\mathrm{Zn}$ and Cd recovery at $\mathrm{pH}$ 8-11.

\subsection{Influence of sulfidization step}

The base-oxide minerals (or oxidized minerals) like zinc and $\mathrm{Cd}$ are more difficult to float, than their sulfide mineral form $[32,21]$. Sulfidizing agents such as $\mathrm{Na}_{2} \mathrm{~S}$ are frequently used 
to produce a sulfide surface. The combination of sulfidization and flotation has been investigated for soil washing applications, because of the heterogeneity of mineralogical forms of metal contaminants in the contaminated soil [17].

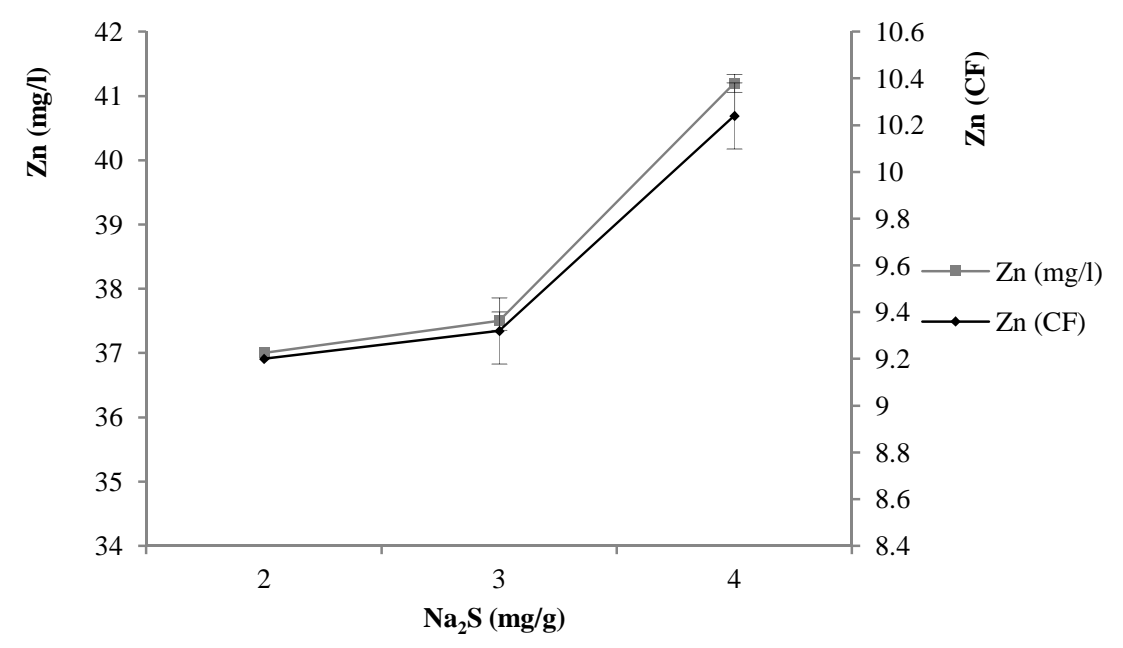

Fig.9. $\mathrm{Na}_{2} \mathrm{~S}$ effect on $\mathrm{Zn}$ flotation at $\mathrm{pH}=12$ in rhmanolipids presence

As shown in figure 9, the pre-treatment by sulfidization $\left(\mathrm{Na}_{2} \mathrm{~S}\right)$ increased $\mathrm{Zn}$ remediation, and the proportional $\mathrm{CF}$ of $\mathrm{Zn}$ depending on the concentration of $\mathrm{Zn}$ in the foam shows a mobilization rate of $\mathrm{Zn}$ which increases with the elevation of $\mathrm{Na}_{2} \mathrm{~S}$ concentration (2 to 4 $\mathrm{mg} / \mathrm{g}$ ), which was $9.2(\mathrm{CF})$ at $\left[\mathrm{Na}_{2} \mathrm{~S}\right]=2 \mathrm{mg} / \mathrm{g}$ and increased by $11.30 \%$ (maximum $\mathrm{CF}=$ 10.24) at $\left[\mathrm{Na}_{2} \mathrm{~S}\right]=4 \mathrm{mg} / \mathrm{g}$. These experimental results could be mainly explained by $\mathrm{Zn}$ presence in sulfide forms $(\mathrm{ZnS})$.

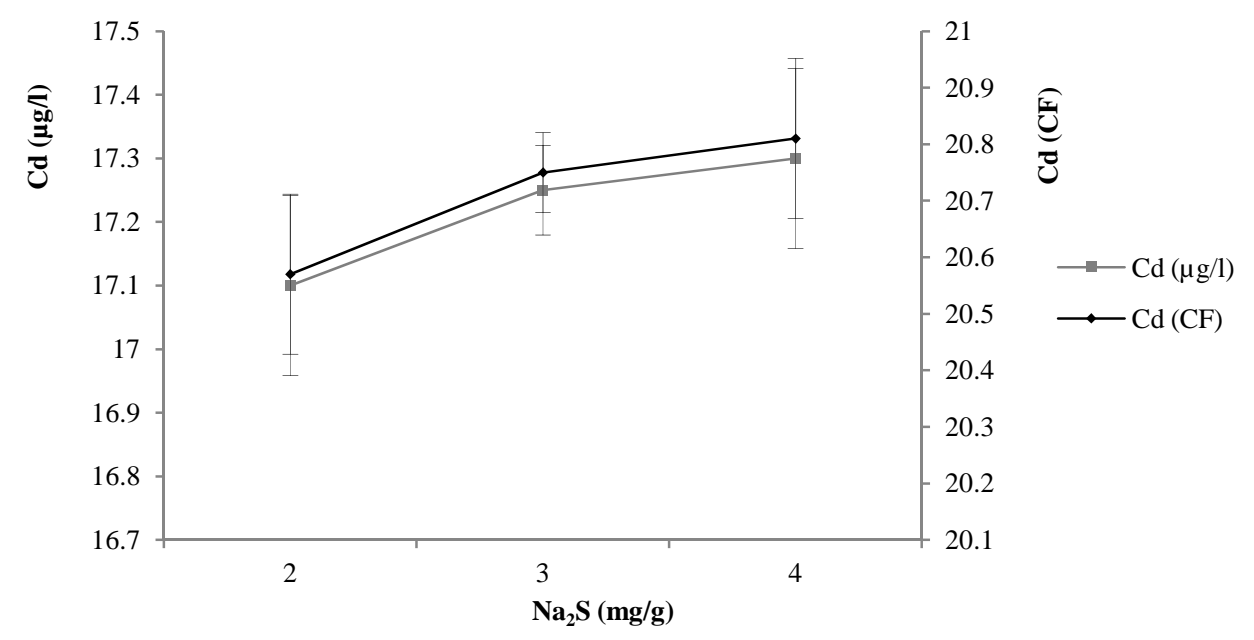

Fig.10. $\mathrm{Na}_{2} \mathrm{~S}$ effect on $\mathrm{Cd}$ flotation at $\mathrm{pH}=12$ in rhmanolipids presence 
The addition of a sulfidization step did not cause a significant change in Cd recovery (Figure 10). $\mathrm{Na}_{2} \mathrm{~S}$ addition seems theoretically attractive, but in practice it suffers from several disadvantages: the different oxide minerals respond differently to sulfidization [33, 34].

Furthermore, the metal removal efficiency using a sulfidization step is low, compared to flotation process, this without chemical activation [35, 36].

\subsection{Influence of flotation time}

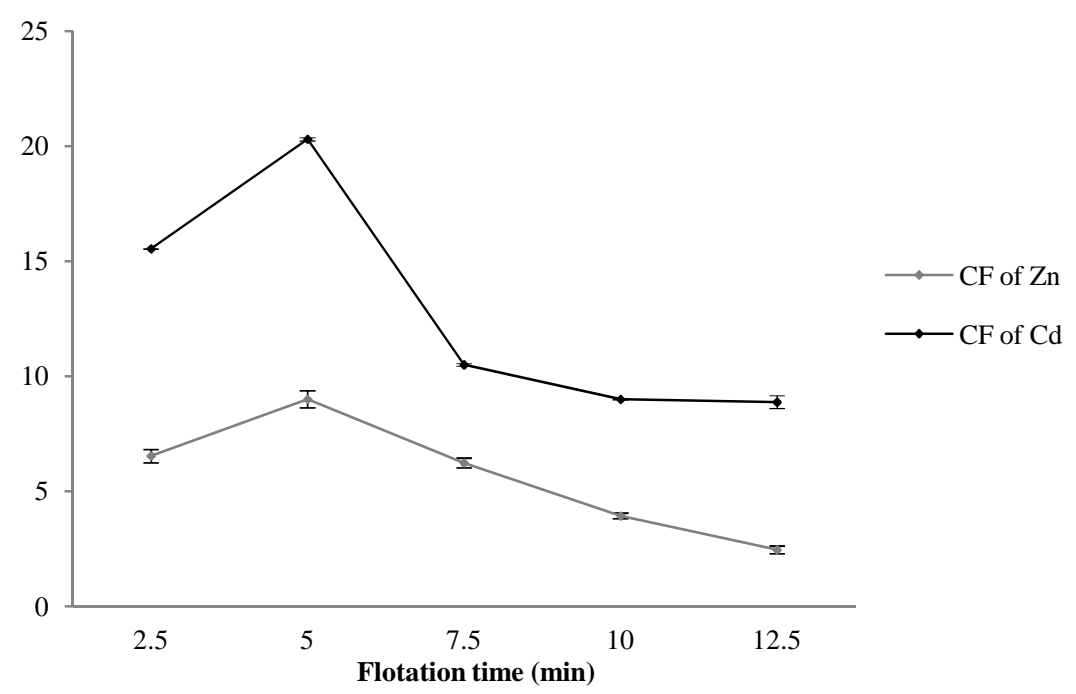

Fig.11. Concentration factors of $\mathrm{Zn}$ and $\mathrm{Cd}$ vs. flotation time. Flotation parameters: $40 \mathrm{mg} / \mathrm{L}$ of rhamnolipids, $4 \mathrm{mg} / \mathrm{g}$ of $\mathrm{Na}_{2} \mathrm{~S}$ and $\mathrm{pH} 12$

Figure 11 shows that the concentration factor of $\mathrm{Zn}$ and $\mathrm{Cd}$ increased until 5 min since the beginning of the flotation, with a raise from 6.54 to 9 between $2.5 \mathrm{~min}$ and $5 \mathrm{~min}$ (an increment of $37.61 \%$ ). For the last period (5-12.5 min), CF of $\mathrm{Zn}$ decreased from 9 to 2.46 (a loss of $72.66 \%$ ).

A raise from 15.54 to 20.3 of the $\mathrm{CF}$ of $\mathrm{Cd}$ was observed between $2.5 \mathrm{~min}$ and $5 \mathrm{~min}$ (an increment of $30.63 \%$ ). For the last period (5-12.5 min) (Figure 11), the CF of Cd decreased from 20.3 to 8.88 (a loss of $56.25 \%$ ). 


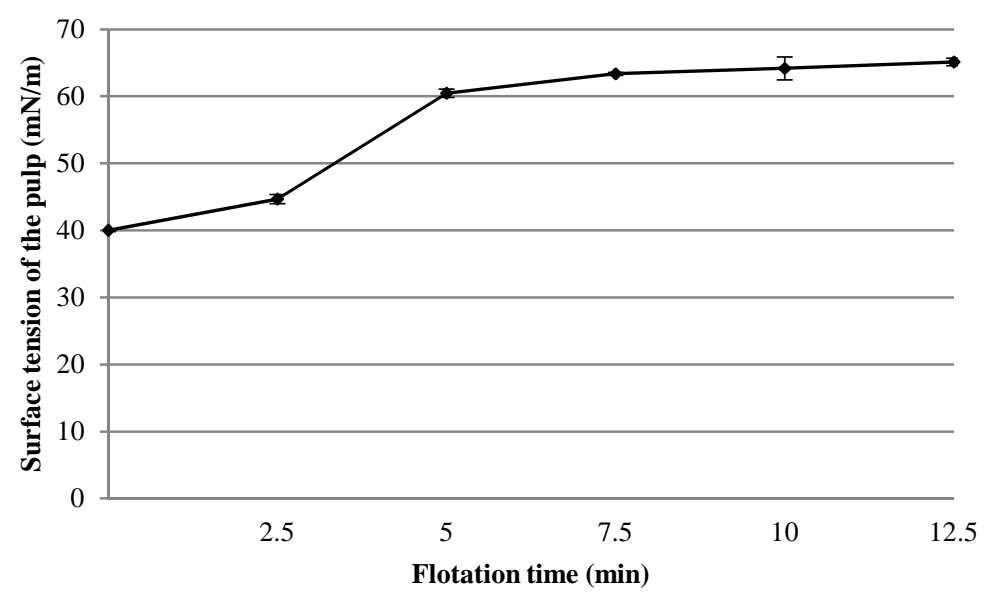

Fig.12. Surface tension $(\mathrm{mN} / \mathrm{m})$ of the pulp vs. flotation time

Figure 12 illustrates an increase of the surface tension of pulp from $\mathrm{T}_{0}$ to $5 \mathrm{~min}$ (40 to 60.46 $\mathrm{mN} / \mathrm{m}$ ) followed by a constant surface tension for the flotation time above $5 \mathrm{~min}$, which can be explained by rhamnolipids loss (movement from the pulp to the froth), thus $\mathrm{Zn}$ and $\mathrm{Cd}$ recovery from the contaminated soil by flotation (after $5 \mathrm{~min}$ ) seems to be entirely due to mechanical entrainment, which is also reliable with Vanthuyne and Maes [36] and et al. findings [17].

\section{CONCLUSIONS}

The efficiency of $\mathrm{Zn}$ and $\mathrm{Cd}$ ions removal by rhamnolipids from soil systems will depend largely on the soil texture, structure, clay content and cations exchange capacity. Soil-washing technology provides rhamnolipids as a reliable solution for the remediation of heavy metal impacted soils. During this study, the chemical activation and the $\mathrm{pH}$ of the pulp significantly influenced the $\mathrm{Zn}$ ions recovery. However, the chemical activation does not caused significant $\mathrm{Cd}$ recovery. Effectiveness of this batch operation using rhamnolipids is strongly affected by the flotation time. In conclusion, the rhamnolipids produced by Pseudomonas aeruginosa S7PS5 were a kind of preferable surface-active substance, having potential application in bioremediation of various soil contaminants.

\section{ACKNOWLEDGMENTS}

The authors of this paper thank Mr. SELOUANI M.M. (Biology department, faculty of 
science, University of Sidi Bel Abbess, Algeria) and Mr. REGUIG O. (Biology department, faculty of science, University of Relizane, Algeria) for their critical support and precious help.

\section{REFERENCES}

[1] Aş̧̧ı Y, Nurbaş M, Sağ Açıkel Y. A comparative study for the sorption of Cd (II) by soils with different clay contents and mineralogy and the recovery of $\mathrm{Cd}$ (II) using rhamnolipid biosurfactant. J. Hazard. Materials, 2008, 154, 663-673.

[2] Alumaa P, Steinnes E, Kirso U, Petersell V. Heavy metal sorption by different estonian soil types at low equilibrium solution concentrations. Proc. Estonian Acad. Sci. Chem, 2001, 50, $104-115$.

[3] Markiewicz-Patkowska J, Hursthouse A, Przybyla-Kij H. The interaction of heavy metals with urban soils: sorption behavior of $\mathrm{Cd}, \mathrm{Cu}, \mathrm{Cr}, \mathrm{Pb}$ and $\mathrm{Zn}$ with a typical mixed brownfield deposit. Environ. Int, 2005, 31, 513-521.

[4] Mulligan C N, Yong R N, Gibbs B F. Remediation technologies for metal-contaminated soils and groundwater: an evaluation. Eng. Geol, 2001, 60, 193-207.

[5] Wang S, Mulligan C N. An evaluation of surfactant foam technology in remediation of contaminated soil. Chemosphere, 2004, 57, 1079-1089.

[6] Mulligan C N. Environmental applications for biosurfactants. Environ. Pollut, 2005, 133, 183-198.

[7] Wan J, Chai L, Lu X, Lin Y, Zhang S. Remediation of hexachlorobenzene contaminated soils by rhamnolipid enhanced soil washing coupled with activated carbon selective adsorption. J. Hazard. Materials, 2011, 189, 458-464.

[8] AFNOR. Qualité des sols, Recueil des normes françaises. AFNOR Edition, 1994, 250.

[9] Bendaha M E-A, Meddah B, Belaouni H A, Tirtouil A. Isolation and biosurfactants production by Pseudomonas aeruginosa S7PS5. J. Chem. Pharm. Res, 2015, 7, (10), $413-422$.

[10] Wei Y H, Chou C L, Chang J S. Rhamnolipid production by indigenous Pseudomonas aeruginosa J4 originating from petrochemical wastewater. Biochem. Eng. J, 2005, 27, $146-154$. 
[11] Jain D K, Thompson D L C, Lee H, Trevors J T. A drop collapsing test for screening surfactant producing microorganisms. J. Microbiol. Meth, 1991, 13, 271-279.

[12] Morikawa M, Daido H, Takao T, Murata S, Imanaka T. A new lipopeptide biosurfactant produced by Arthrobacter sp. strain MIS38. J. Bacteriol, 1993, 175, 6459-6466.

[13] Paraszkiewicz K, Kanwal A, Dlugonski J. Emulsifier production by steroid transforming filamentous fungus Curvularia lunata. Growth and product characterization. $J$. Biotechnol, 2002, 92, 287-29.

[14] Zajic J E, Seffens W. Biosurfactants. C.R.C. Crit. Rev. Biotechnol, 1984, 1, (2), 87-107. [15] Chen C C, Riadi L, Suh S J, Ohman D E, Ju LK. Degradation and synthesis kinetics of quorum-sensing autoinducer in Pseudomonas aeruginosa cultivation. J. Biotechnol, 2005, 117, 1-10.

[16] Yin H, Qiang J, Jia Y, Ye J, Peng H, Qin H, Zhang N, He B. Characteristics of biosurfactant produced by Pseudomonas aeruginosa S6 isolated from oil containing waste water. Process Biochem, 2009, 44, 302-308.

[17] Dermont G, Bergeron M, Richer-Laflèche M, Mercier G. Remediation of metal-contaminated urban soil using flotation technique. Sci. of Total Envir, 2010, 408, 1199-1211.

[18] Dermont G. Sols pollués par les métaux lourds résultant de l'enfouissement de déchets industriels (Montréal, Canada), Géochimie, spéciation des métaux, et décontamination par flottation, Dissertation. University of Quebec, Canada, 2008.

[19] West C C, Harwell J H. Surfactants and subsurface remediation. Environ. Sci. Technol, 1992, 36, (12), 2324-2330.

[20] Herrera-Urbina R, Sotillo F J, Fuerstenau D W. Effect of sodium sulfide additions on the pulp potential and amyl xanthate flotation of cerussite and galena. Int. J. Miner. Process, 1999, $55,157-170$.

[21] Rashchi F, Dashti A, Arabpour-Yazdi M, Abdizadeh H. Anglesite flotation: a study for lead recovery from zinc leach residue. Miner. Eng, 2005, 18, 205-12.

[22] Candrasekaran E V, Bemiller J N. Constituent analyses of glycosamino-glycans, In: methods in carbohydrate chemistry. New York: Academic Press, 1980. 
[23] Bai G, Brusseau M L, Miller R M. Influence of cation type, ionic strength, and $\mathrm{pH}$ on solubilization and mobilization of residual hydrocarbon by a biosurfactant. J. Contam. Hydrol, 1998, 30, 265-279.

[24] Miller-Maier R M, Bodour A A. Application of a modified dropcollapse technique for surfactant quantitation and screening of biosurfactant-producing microorganisms. J. Microbiol. Method, 1998, 32, 273-280.

[25] Maier R M, Soberon-Chavez G. Pseudomonas aerugionsa rhamnolipids: biosynthesis and potential applications. Appl. Microbiol. Biotechnol, 2000, 54, 625-633.

[26] Baize D. Teneurs totales en éléments traces métalliques dans les sols (France). Paris : INRA Editions, 1997, 408.

[27] Bourg C M. Metal in aquatic and terrestrial systems: sorption, speciation and mobilisation. In Chemistry and biology of solid waste, Springer, New York, USA,1988. [28] Bourg, C M. Modélisation du comportement des métaux traces à l'interface solide-liquide dans les systèmes aquatiques, dissertation. University of Bordeaux 1, France. 1983. [29] Bouchard, S. Traitement du minerai: Flottation. In Méthodes physiques, le Griffon d'argile, ISBN 2-89443-156-2. Canada, Montreal, 2001.

[30] Frazer L. Innovations, lipid lather removes metals. Environ. Health Perspect, 2000, 108, 320-323.

[31] Fuerstenau C. Froth flotation: a century of innovation, Society for Mining, Metallurgy, and Exploration (SME), Littleton, USA, 2007.

[32] Rao S R, Leja J. Surface chemistry of froth flotation. New York: Kluwer Academic Publishers, 2004.

[33] Shen W Z, Fornasiero D, Ralston J. Flotation of sphalerite and pyrite in the presence of sodium sulfite. Int. J. Miner. Process, 2001, 63, 17-28.

[34] Newell A J H, Skinner W M, Bradshaw D J. Restoring the floatability of oxidised sulfides using sulfidisation. Int. J. Miner. Process, 2007, 84, 108-17.

[35] Venghaus T, Werther J. Flotation of a zinc-contaminated soil. Adv. Environ. Res, 1998, 2, 77-91.

[36] Vanthuyne M, Maes A. The removal of heavy metals from contaminated soil by a 
combination of sulfidisation and flotation. Sci. Total. Environ, 2002, 290, 69-80.

\section{How to cite this article:}

Bendaha M E-A, Meddah B, Belaouni H A, Tirtouil A. Removal of Zinc and Cadmium ions from Contaminated Soils with Rhamnolipid Biosurfactant Produced by Pseudomonas aeruginosa S7PS5. J. Fundam. Appl. Sci., 2016, 8(3), 1146-1165. 